\title{
Towards 6G: Getting Ready for the Next Decade
}

\author{
Marcos Katz, Pekka Pirinen, and Harri Posti \\ Centre for Wireless Communications, University of Oulu, Finland \\ name.surname@oulu.fi
}

\begin{abstract}
As the wireless and mobile world is turning its interest into beyond 5G development, industry and research community are gradually taking up this colossal challenge. This paper discusses the readiness and capacity needed to develop beyond 5G (B5G) and $6 G$ technology and their associated businesses and applications. The wireless landscape is analyzed in different timeframes covering roughly the period between 2020 and 2030 , the decade where B5G and 6G are expected to be fully developed. After discussing relevant trends and key requirements needed to develop B5G and 6G in general, the paper will consider, as a particular example, the current development and readiness of Finland. With a strong background in $5 \mathrm{G}$, Finland is one of the first countries to start doing $6 \mathrm{G}$ development following a large research project where key industrial and academic players of the country participate. Hopefully, the conceived developing path to $6 \mathrm{G}$ presented in this paper will serve a motivational guide to other developers.
\end{abstract}

Keywords-wireless communications, mobile communications, B5G, 6G, 5G evolution, future wireless and mobile networks, developing $6 G$

\section{INTRODUCTION}

As the development of $5 \mathrm{G}$ technology is moving to its final phase and the deployment of $5 \mathrm{G}$ networks is imminent, there is an increasing interest by the industrial, academic and regulatory communities to start researching and developing the next generation networks. In this paper, beyond 5G networks (B5G) are called 6G. It is expected that the next decade, 2020-2030, will be devoted to the development of future $6 \mathrm{G}$ networks. More than ever, joint efforts from a large and eclectic stakeholders base is needed to create the $6 \mathrm{G}$ ecosystem. The role of this paper is manifold. It will first discuss emerging trends, which will help to further delineate important characteristics of future $6 \mathrm{G}$. This will be done not only from a technical perspective, as done in previous generations, but considering social and economic standpoints. Then the paper will focus on the key skills and capabilities needed to develop 6G. Finally, a case study will be presented considering Finland and its 6G Flagship Project as examples of future mobile and wireless communications systems. The overall goal of this paper is to shed some light on the current situation as well as expected developments of wireless and mobile communications globally and in Finland, highlighting the current state, key development goals for future networks as well as some challenges. Finland is one of the first countries to start researching 6G, with its large-scale research initiative 6Genesis Flagship Project, an eight-year program (2018-2026) funded by the Finnish government through the Academy of Finland [1].

\section{TOWARDS 6G: GLOBAL TRENDS}

After four decades of development and four generations of mobile networks, the global penetration of wireless portable devices such as smartphones, tablets, etc. well exceeds $100 \%$. Vehicular connectivity and machine-to-machine (M2M) communications are growing at a very fast pace. By 2025 it is expected that all new cars will support connections to internet. In each of these segments, the number of nodes to be served is measured by billions. The final connectivity frontier is defined by the internet of things (IoT) paradigm, allowing in principle any object to be networked wirelessly. The number of potential nodes is measured by trillions. Providing truly massive connectivity across the globe requires the joint operation of short-range, cellular and satellite networks. In addition to high network capacity, requirements for significantly higher link capacity are also expected. Transmission of high-definition video, virtual reality, holographic images as well as very demanding industrial applications are examples of high bandwidth, high data rate requirements for wireless links. The vigorous growth in traffic means a high demand for new spectrum. This has created a pressure to move towards higher and higher frequency bands, which are less congested and offer considerably wider bandwidths. Local access typically exploits unregulated spectrum whereas large area coverage (cellular and satellite) need to use regulated frequency bands. Millimeter-wave and $\mathrm{THz}$ bands are currently being investigated and trialed.

Shifting to higher frequencies brings more resources to the design table but also considerable challenges. Radio design becomes more complex. Moreover, propagation characteristics of high frequency radiowaves will have a direct impact on network architecture of future cellular systems, where coverage will be provided by a dense network of base stations. In addition to the conventional radio communications considered for $6 \mathrm{G}$ (covering possibly from sub- $\mathrm{GHz}$ to $\mathrm{THz}$ bands), optical wireless communications, particularly visible light communication (VLC), has been considered as a complementing technology to radio. The concept of tactile internet, calling for very short end-to-end delays ( $1 \mathrm{~ms}$ and below), will be exploited in a variety of applications, such as industrial, transport, healthcare and entertainment. Lowlatency requirements will have an impact on the network architecture, as over-the-air propagation, transportation- and processing-time need to be minimized. Other requirements that will become very relevant in $6 \mathrm{G}$ are high reliability, security and privacy. Reliable wireless communications are essential for many important scenarios, such a healthcare, industrial internet, and vehicular networks. Along these lines, many advanced services and applications will be used only if highly secure and private connections are guaranteed. Recently, increasing concern on possible health impact of very high frequency electromagnetic radiation on human beings is expected also to be considered in the development of $6 \mathrm{G}$.

$6 \mathrm{G}$ development is expected be driven also by other values. When designing 6G, social aspects should not be ignored. Despite impressive figures on global penetration, digital inclusion is a problem that has not been tackled by previous mobile generations. In fact, regardless of the optimistic predictions of creating a truly connected planet exploiting wireless communications, the digital divide has significantly grown, and today there are several billion people well outside of the connected world. 6G should be 
designed also with this social responsibility, bringing connectivity to every citizen of the world, particularly those who live under severe economic constraints and in remote or underdeveloped regions. A truly connected world is a key precondition for an equitable and prosperous world. This subject is not only related to political and economic decisions but also to the development of technical solutions, novel business models, spectrum allocation and flexible regulation, among others. Combining the aforementioned local, cellular and satellite access in a flexible platform operation, supported by a sustainable economic model, should be already included in the $6 \mathrm{G}$ drawing table.

The development of $6 \mathrm{G}$ is expected to take place along with the creation and further development of vertical markets, with very specific needs and requirements. Examples of future vertical markets include industrial-grade internet, massive IoT sensing for healthcare, energy grids and many others.

Fig. 1 depicts our view of the potential 6G ecosystem, highlighting the constituent networks and key stakeholders to be connected. Given the scale of nodes to be connected and their eclectic requirements, and taking into account the cost of every connection in terms of energy, spectrum, time, etc., in the realm of $6 \mathrm{G}$ the term "everything connected" should be understood as "everything consciously connected".

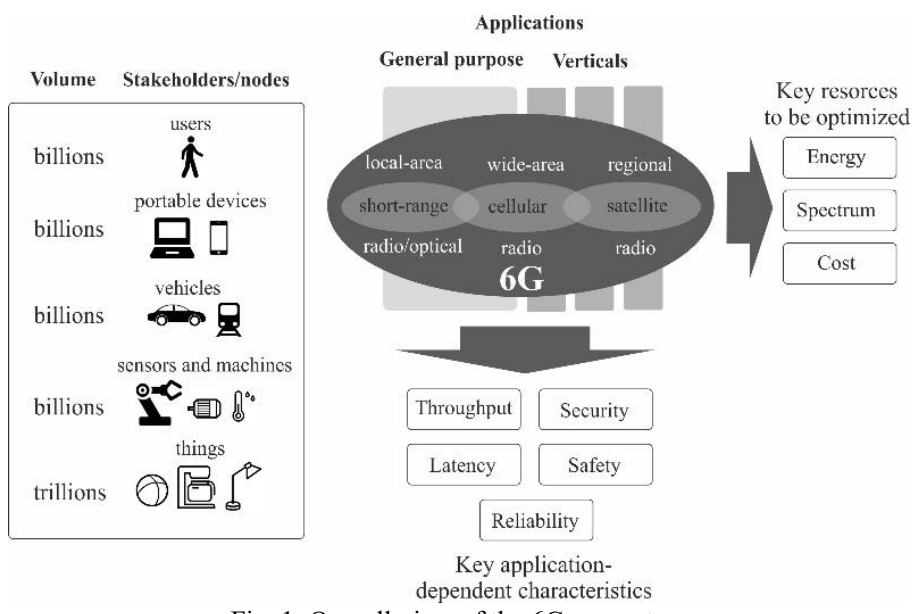

Fig. 1. Overall view of the $6 \mathrm{G}$ ecosystem.

WHAT Do WE NEED TO DEVELOP FOR 6G?

$5 \mathrm{G}$ has introduced many new network orchestration tools in the form of softwarization and virtualization. This includes, e.g., the concept of network slicing that helps in coping with diverse use cases requiring different levels of data rate, latency and reliability (to name a few common key performance indicators, KPIs). It is likely that all the anticipated $5 \mathrm{G}$ functionalities do not come to full fruition before $6 \mathrm{G}$ era, and therefore need to be developed further.

From the air-interface perspective the expected peak data rate continues to increase and should surpass $1 \mathrm{~Tb} / \mathrm{s}$ mark. Augmented reality/virtual reality (AR/VR) applications are data hungry and even more so is their next evolution step to multi-sense holography. Expanding amount of wireless data traffic is not sustainable without major advances in energy efficiency. Energy harvesting may eventually remove the need for charging mobile appliances.

RF and HW expertise need to be extended to higher frequencies, and by doing that, new paradigms for transceiver architectures and computing can be developed. Balancing between performance and cost needs to be done to keep HW affordable to customers. Potential breakthroughs in optics and materials will be followed closely. As the center frequencies go up many HW components can be packed tighter, e.g., antennas get minuscular and can be integrated into the chip.

People are getting more and more dependent on the digital world. This then necessitates trust, privacy, and security to be major drivers in the development of $6 \mathrm{G}$ networking. Machine learning (ML) and artificial intelligence (AI) are already gaining momentum, and are expected to be in an important role mining the Big Data in 6G. Mobile edge computing and intelligence will be key enablers for $6 \mathrm{G}$ services. Block chains and distributed ledgers are emerging technologies that may have influence on how $6 \mathrm{G}$ networks take shape.

As seen from the 17 global goals for sustainable development declared by the United Nations [2], we are facing multifaceted challenges related to, e.g., climate change, growing and ageing population, poverty, urbanization, and equality. At first sight, many of these seem not to be $6 \mathrm{G}$ topics. However, with a closer inspection, it appears that ICT technologies including 6G, will have a significant role in most of them if not all.

\section{CASE STUdY: FinLAND}

The wireless and mobile world, including Finland, is starting to move towards the development of B5G and $6 \mathrm{G}$ technologies. At a quite early stage, Finland is aiming at taking a leading role in $6 \mathrm{G}$, understanding the opportunities that this may bring, and strongly investing in developing $6 \mathrm{G}$ technologies. Finland is used as a case study on $6 \mathrm{G}$ development, which hopefully will be useful to researchers, engineers and developers of $6 \mathrm{G}$. The development plan is described in term of current, short- and long-term milestones.

\section{A) The Wireless Scene in Finland}

The current and future Finnish wireless communication scene is briefly described from the research, business and society standpoints in Table I. Research-wise, development on smart networks ( $\mathrm{SN}$ ) and $\mathrm{B} 5 \mathrm{G}$ is well in progress, paving the way to the development of $6 \mathrm{G}$. The imminent deployment of $5 \mathrm{G}$ networks will accelerate the development of $5 \mathrm{G}$ business, as well as the launching of vertical $5 \mathrm{G}$ applications. The willingness and enthusiasm of Finnish society to welcome innovation will certainly be exploited. Also, many cities and organizations in Finland are always eager to test innovation. In recent years, there has been a substantial grow in ICT workforce, particularly in software development, contrasted by an overall decrease of manufacturing personnel [3]. Similar trends apply for revenues, where a constant growth is observed in software sales, while equipment sales have declined considerably, though becoming steady lately [3].

Since Finland has a strong background in developing $5 \mathrm{G}$ technology, see first row in Table I, the country is well positioned to continue with the development of the successor network. Multiple advanced 5G testbeds have been deployed and tested across the country, allowing to test novel technologies and vertical applications. Society as well as cities have been used as living laboratories to test novel ideas. 
TABLE I. WIRELESS COMMUNICATIONS IN FINLAND FROM THE RESEARCH, BUSINESS AND SOCIETY STANDPOINTS.

\begin{tabular}{|c|c|c|c|}
\hline & Research & Business & Society \\
\hline Now & $\begin{array}{l}\text { - Further development of } \\
\text { vertical solutions based } \\
\text { on } 5 \mathrm{G} \text { and beyond (e.g. } \\
3 \mathrm{GPP} / \\
\text { REL16 } \rightarrow \text { ) } \\
\text { - Research on Smart } \\
\text { Networks (SN) starts. } \\
\text { - Further research of } \\
\text { satellite } \\
\text { communication. }\end{array}$ & $\begin{array}{l}\text { - 5G business } \\
\text { about to be } \\
\text { launched. }\end{array}$ & $\begin{array}{l}\text { - Wide } \\
\text { availability of } \\
\text { services based } \\
\text { on wireless } \\
\text { internet. }\end{array}$ \\
\hline $\begin{array}{c}\text { In } 5 \\
\text { years }\end{array}$ & $\begin{array}{l}\text { - Research of SN (B5G) } \\
\text { at its peak. } \\
\text { - Optimization of } \\
\text { integration between 5G } \\
\text { and satellite networks. } \\
\text { - Research testbed } \\
\text { applies flexibly } \\
\text { frequencies and } \\
\text { network infrastructure } \\
\text { of commercial } \\
\text { operators in Finland. } \\
\text { - 6G research rapidly } \\
\text { increasing. }\end{array}$ & $\begin{array}{l}\text { - } 5 \mathrm{G} \text { coverage } \\
\text { equal to current } \\
\text { 4G. } \\
\text { - Initial SN (B5G) } \\
\text { deployment. } \\
\text { - Initial } \\
\text { integration of } \\
\text { satellite } \\
\text { networks with } \\
\text { land networks. }\end{array}$ & $\begin{array}{l}\text { - 5G-based M2M } \\
\text { communications } \\
\text {, systems and } \\
\text { services in } \\
\text { vertical } \\
\text { industries. } \\
\text { - 5G-based } \\
\text { mobile } \\
\text { wideband } \\
\text { services widely } \\
\text { used (e.g., } \\
\text { AR/VR). }\end{array}$ \\
\hline $\begin{array}{l}\text { In } 10 \\
\text { years }\end{array}$ & $\begin{array}{l}\text { - Optimized } \\
\text { implementation of SN. } \\
\text { - Significant increase in } \\
\text { research of disruptive } \\
\text { communication: light, } \\
\text { nano-, bionano- and } \\
\text { quantum- } \\
\text { communications. }\end{array}$ & $\begin{array}{l}\text { - } 5 \text { G reaches full } \\
\text { coverage. } \\
\text { - Satellite } \\
\text { networks } \\
\text { partially } \\
\text { integrated to } \\
\text { land networks. } \\
\text { - Deployment of } \\
\text { commercial 6G } \\
\text { networks starts. }\end{array}$ & $\begin{array}{l}\text { - Starting the } \\
\text { integration of IT } \\
\text { systems with } \\
\text { artificial } \\
\text { intelligence (AI) } \\
\text { and machine } \\
\text { learning (ML) as } \\
\text { part of the } \\
\text { societal } \\
\text { structure. }\end{array}$ \\
\hline
\end{tabular}

\section{B) Finnish Position: Strengths, Weaknesses, Opportunities and Threats}

Table II identifies Finnish strengths, opportunities, weaknesses and threats in terms of global trends for $\mathrm{B} 5 \mathrm{G}$ and $6 \mathrm{G}$, in the present and the future. As a whole, Finland is well positioned and prepared to develop a $6 \mathrm{G}$ ecosystem. 5G technology has been developed, implemented and tested widely by companies as well as academia. Companies also continue to develop vertical applications matched to the capabilities of $5 \mathrm{G}$. Risks have been identified, for instance possible funding limitation, particularly towards the end of the decade, lack of experts in specific research areas and research volume compared to bigger countries. On the other hand, Finland can be considered a model country for developing 6G. Research institutions are all well connected and their cooperation with industry (telecom, operators, SMEs, etc.) has a long tradition. Authorities, politicians and technology experts have smooth relations with operators and the Finnish Transport and Communications Agency (TRAFICOM) [4]. Finland is determined to develop and implement 6G successfully in the next decade.

Finland being strong in key areas of $5 \mathrm{G}$ technology (radio, networks, signal processing and testbeds) and considering the efficient nationwide cooperation, the country is in a privileged position to start conducting $6 \mathrm{G}$ research. Business-wise, Nokia, a global telecom player, is still a significant actor in Finland. New startups are being established at an increasing pace, and many
Finnish cities work as open testbeds, evaluating novel technologies and concepts, such as in the case of 6AIKA [5] ja LuxTurrim5G [6].

TABLE II. B5G AND 6G IN FINLAND: TODAY AND TOMORROW.

\begin{tabular}{|c|c|c|c|c|}
\hline & Strengths & Weaknesses & Opportunities & Threats \\
\hline Now & $\begin{array}{l}\text { Nokia } \\
\text { ecosystem } \\
\text { competence } \\
\text { in } 4 \mathrm{G} \text { and } 5 \mathrm{G} \\
\text { radio } \\
\text { technology } \\
\text { and business. } \\
\text { Advanced } \\
\text { testing } \\
\text { environments } \\
\text { and } \\
\text { ecosystems } \\
\text { for } \\
\text { developing } \\
\text { 5G evolution. }\end{array}$ & $\begin{array}{l}\text { - Understandin } \\
\text { g of vertical } \\
\text { industry } \\
\text { requirements. } \\
\text { - Small } \\
\text { industry } \\
\text { ecosystem. } \\
\text { - Modest role } \\
\text { in other than } \\
\text { 3GPP } \\
\text { technologies. }\end{array}$ & $\begin{array}{l}\text { - } 5 \mathrm{G} \text { - based } \\
\text { solutions for } \\
\text { vertical } \\
\text { industries. } \\
\text { - Integration of } \\
\text { satellite } \\
\text { communication } \\
\text { s. } \\
\text { - Poor reputation } \\
\text { of Chinese } \\
\text { telecom } \\
\text { companies. }\end{array}$ & $\begin{array}{l}\text { - The role of } \\
\text { Finland in } \\
\text { Nokia } \\
\text { decreases. } \\
\text { - Limited } \\
\text { application of } \\
\text { AI/ML slows } \\
\text { down the } \\
\text { competitiven } \\
\text { ess growth. } \\
\text { - Demand by } \\
\text { satellite } \\
\text { communicatio } \\
\text { ns cannot be } \\
\text { answered. }\end{array}$ \\
\hline $\begin{array}{c}\text { In } 3 \\
\text { years }\end{array}$ & $\begin{array}{l}\text { Availability } \\
\text { of B5G } \\
\text { technologies. } \\
\text { Developed } \\
\text { expertise in } \\
\text { AI/ML and } \\
\text { cybersecurity } \\
\text {, application } \\
\text { of these in } \\
\text { vertical } \\
\text { industries. }\end{array}$ & $\begin{array}{l}\text { - Research } \\
\text { volume } \\
\text { compared to } \\
\text { Asia, } \\
\text { America and } \\
\text { Europe. } \\
\text { - Dependence } \\
\text { on Nokia's } \\
\text { position. }\end{array}$ & $\begin{array}{l}\text { - Exploitation of } \\
\text { B5G } \\
\text { technologies, } \\
\text { AI/ML- and } \\
\text { cybersecurity } \\
\text { in vertical } \\
\text { solutions. } \\
\text { - Development } \\
\text { of Smart } \\
\text { Network } \\
\text { technology and } \\
\text { the 6G concept. } \\
\text { - Evolution of } \\
\text { core network } \\
\text { driven by radio } \\
\text { interface } \\
\text { functionalities. }\end{array}$ & $\begin{array}{l}\text { - Lacking } \\
\text { proper focus } \\
\text { of limited } \\
\text { research } \\
\text { volume. } \\
\text { - Moving to } \\
\text { considerably } \\
\text { higher } \\
\text { frequency } \\
\text { bands (e.g., } \\
\text { mm-wave } \\
\text { and THz) } \\
\text { might be } \\
\text { more difficult } \\
\text { than } \\
\text { expected. }\end{array}$ \\
\hline $\begin{array}{c}\text { In } 5 \\
\text { years }\end{array}$ & $\begin{array}{l}\text { 6Genesis- } \\
\text { flagship [1]. }\end{array}$ & $\begin{array}{l}\text { - Availability } \\
\text { of research } \\
\text { funds. }\end{array}$ & $\begin{array}{l}\text { - New vertical } \\
\text { business } \\
\text { created by } 5 \mathrm{G} \text {. } \\
\text { - Technology } \\
\text { lead in mm- } \\
\text { wave RF and } \\
\text { optical design } \\
\text { and } \\
\text { technologies. } \\
\text { - Proficient } \\
\text { application of } \\
\text { AI/big } \\
\text { data/security/ed } \\
\text { ge computing. } \\
\text { - Regulations' } \\
\text { support of } \\
\text { ecosystem } \\
\text { creation. }\end{array}$ & $\begin{array}{l}\text { - Shortage of } \\
\text { skilled labor } \\
\text { in the field. }\end{array}$ \\
\hline $\begin{array}{l}\text { In } 10 \\
\text { years }\end{array}$ & $\begin{array}{l}\text { Multi- } \\
\text { discipline } 6 \mathrm{G} \\
\text { capability. }\end{array}$ & $\begin{array}{l}\text { - Availability } \\
\text { of research } \\
\text { funds. }\end{array}$ & $\begin{array}{l}\text { - Finland is a } \\
\text { forerunner in } \\
\text { B5G/6G } \\
\text { technologies. } \\
\text { - Expansion of } \\
\text { competences to } \\
\text { the fields } \\
\text { required by } \\
\text { network } \\
\text { convergence. }\end{array}$ & $\begin{array}{l}\text { - Shortage of } \\
\text { skilled labor } \\
\text { in the field. }\end{array}$ \\
\hline
\end{tabular}

Finland, with the role of Nokia and other local key players, was instrumental to develop, implement and market successfully previous and current mobile communications technologies, from $1 \mathrm{G}$ up to $5 \mathrm{G}$. Finland is resolved and committed to continue along 
this success path and to create a leading 6G ecosystem. As highlighted in [7], building the $6 \mathrm{G}$ ecosystem requires multidisciplinary know-how, not only in the conventional wireless field, but also in other areas, such as $\mathrm{AI} / \mathrm{ML}$, distributed computing, material science, high-frequency electronics, and many others. A great deal of expertise and efforts are required to make 6G a reality. Despite its name, the Finnish 6G ecosystem does not consist solely of Finnish partners but it is also an open ecosystem welcoming any business or research organization willing to join.

\section{THE WAY FORWARD}

Next decade will be crucial for the development of $6 \mathrm{G}$ ecosystem, starting from requirements identification all the way to system design and development, creation and adoption of novel technologies, standardization and network trialing. Table III shows $5 \mathrm{G}$ and $6 \mathrm{G}$ technology milestones for the upcoming three, five and ten years. Fundamental for the development of $6 \mathrm{G}$ is the successful deployment and rapid adoption of 5G technology. This should be hopefully be evident after a few years $5 \mathrm{G}$ networks are introduced. Unlike former generations, $6 \mathrm{G}$ will be the first wireless and mobile ecosystem that will be developed around truly multidisciplinary requirements. Technical requirements, the ultimate specifications needed to define and design $6 \mathrm{G}$, will come as the result of a joint analysis of user expectations, social needs, requirements of vertical applications, availability of spectrum, economic constraints, regulations and many others.

A common understanding on the frequency bands and available bandwidths usage for $6 \mathrm{G}$ needs to be reached already in an early stage of the development. Only after decisions on frequency allocations for $6 \mathrm{G}$ are made, network architecture can be ultimately designed, as simulations, experimental work and trials are needed to estimate how dense access node networks should be, and what are the requirements for backhauling.

In the mid of next decade, a great deal of decisions on $6 \mathrm{G}$ network and component technology should be done. In addition, the most relevant algorithms, signal processing, and $\mathrm{AI} / \mathrm{ML}$ approaches should be evaluated and compared. Testing of component networks at this time should be ongoing and initial integration work towards the final heterogeneous should start.

Undoubtedly, cooperation between industry, academia, regulators and political decision makers is crucial for the development of $6 \mathrm{G}$. More than ever, developing the next generation of mobile and wireless communication will be a colossal task requiring global cooperation. At this initial phase, creating a common ground for discussions and understanding $6 \mathrm{G}$ and its requirements and challenges is highly necessary. 6G Flagship Project [1] is in the process of preparing a white paper on key areas of $6 \mathrm{G}$ development. This paper is written with the collaboration of global specialists from industry, academia and regulators, and its first version will be available in Q3/2019. A motivating insight of how $6 \mathrm{G}$ transforms our daily life can be seen in [8], where a high-level vision of the $6 \mathrm{G}$ impact is presented. Other visions on $\mathrm{B} 5 \mathrm{G}$ and $6 \mathrm{G}$ are discussed in [9]-[11].
TABLE III. 5G AND 6G TECHNOLOGY MiLESTONES.

\begin{tabular}{|c|c|}
\hline & Milestones \\
\hline $\begin{array}{c}\text { In } 3 \\
\text { years }\end{array}$ & $\begin{array}{l}\text { - Worldwide } 5 \mathrm{G} \text { network deployment continues. } 5 \mathrm{G} \text { services } \\
\text { available in large cities. } \\
\text { - Vertical solutions exploiting } 5 \mathrm{G} \text { evolution, AI/ML and } \\
\text { cybersecurity (e.g., manufacturing, transport and logistics, } \\
\text { connected cars, media, health and wellbeing). } \\
\text { - 6G community starts collecting feedback from 5G community. }\end{array}$ \\
\hline $\begin{array}{c}\text { In } 5 \\
\text { years }\end{array}$ & $\begin{array}{l}\text { - Common understanding on 6G frequency bands to be used. } \\
\text { - Architecture and core technologies for smart networks developed. } \\
\text { - Increased share of satellite communications. } \\
\text { - Operational national research networks allowing flexible sharing of } \\
\text { 5G spectrum and network infrastructure with commercial } \\
\text { operators. } \\
\text { - 5G business and vertical segments well developed. } \\
\text { - 5G-6G community discussions: 6G community exploits knowledge } \\
\text { from 5G (successful and unsuccessful experiences, technology } \\
\text { issues, unreached goals, etc.). } \\
\text { - Core technologies for 6G selected and tested (RF, mm-wave, THz, } \\
\text { optical). } \\
\text { - Extensive 6G algorithms, signal processing and applied AI/ML } \\
\text { evaluated and compared. } \\
\text { - Well underway testing and evaluations of component networks of } \\
\text { 6G. } \\
\text { - Integration work towards experimental 6G testbed starts. }\end{array}$ \\
\hline $\begin{array}{l}\text { In } 10 \\
\text { years }\end{array}$ & $\begin{array}{l}\text { - Technology leadership in smart networks and 6G. } \\
\text { - Advanced technologies for smart networks: Architecture, unifying } \\
\text { control framework, radio and network technologies, distributed } \\
\text { computing AI/ML, cybersecurity. } \\
\text { - Exploitation of AI/ML and cybersecurity in SN and 6G verticals. } \\
\text { - Advanced radio technologies and DSP: Concepts, methods and } \\
\text { implementation technologies (antennas, WR, SW/HW). } \\
\text { - Integration of land and satellite networks. } \\
\text { - Companies and business size in the field increased significantly. }\end{array}$ \\
\hline
\end{tabular}

\section{CONCLUSION}

$6 \mathrm{G}$ is poised to take major technical steps forward; perhaps bigger ones than any previous wireless generation has attempted. An example of such can be found in the radio technology itself, with its leap to Terahertz frequencies. The related challenges regarding materials, electrical components and production processes cannot overestimated. Another major issue in the physical domain is energy consumption. The vision of data speeds and volumes increasing again by several magnitudes of order calls for breakthrough innovations in signal processing technologies. With the present level of consumed energy per processed bit, it is impossible to build the envisioned system. Finally, 6G networks will possess extremely high levels of complexity. Thus, in addition to transporting huge amounts of data, they will internally create plenty of configuration and status-related information. The volume of this data will be such that advanced big data management and data analytics will be required to maintain the networks and to keep them running efficiently and reliably.

As stated, overcoming these and other $6 \mathrm{G}$ challenges calls for wide international cooperation in the fields of academics and industries. The case study above also indicated that Finland is among those countries with an advantageous starting position for $6 \mathrm{G}$. 


\section{ACKNOWLEDGMENT}

The authors would like to thank all other Allied ICT Finland wireless communications work group participants for stimulating discussions and contributions for the Finnish case study.

\section{REFERENCES}

[1] 6G Flagship. [Online]. Available: https://www.oulu.fi/6gflagship/

[2] United Nations Sustainable Development Goals. [Online]. Available: https://www.un.org/sustainabledevelopment/sustainable-developmentgoals/

[3] Statistics Finland. [Online]. Available: https://www.stat.fi

[4] TRAFICOM. [Online]. Available: https://www.traficom.fi

[5] 6AIKA. [Online]. Available: https://6aika.fi
[6] LuxTurrim5G. [Online]. Available: https://www.luxturrim5g.com

[7] M. Katz, M. Matinmikko-Blue, and M. Latva-aho, "6Genesis flagship project: Building the bridges towards 6G-enabled wireless smart society and ecosystem," in Proc. IEEE LatinCom, Nov. 2018, pp. 1-6.

[8] 6G Genesis Vision. https://www.youtube.com/watch?v=T6ubRoZCeVw

[9] K. David and H. Berndt, " $6 \mathrm{G}$ vision and requirements: Is there any need for beyond 5G?," IEEE Vehicular Technology Magazine, vol. 13, no. 3, pp. 7280, Sep. 2018.

[10] H. Elayan, O. Amin, R. M. Shubair, and M.-S. Alouini, "Terahertz communication: The opportunities of wireless technology beyond 5G," in Proc. 2018 International Conference on Advanced Communication Technologies and Networking, Apr. 2018, pp. 1-5.

[11] V. Raghavan and J. Li, "Evolution of physical-layer communications research in the post-5G era," IEEE Access, vol. 7, pp. 10392-10401, Jan. 2019. 